UDC 378.147: 811.111

DOI: $10.17223 / 24109266 / 10 / 13$

\title{
AKMELINGUISTIK IM KONTEXT DER MODERNEN HOCHSCHULAUSBILDUNG
}

\author{
E.A. Merts, E.V. Zhitkova
}

\begin{abstract}
Zusammenfassung. Die innovativen Prozesse in der Gesellschaft, Wirtschaft und im Bildungswesen von heute fordern neue Standards und Ausbildungsansätze. Die methodisch-didaktischen Möglichkeiten der Ausbildung tragen dazu bei, dass die Kenntnisse zugänglicher und die Studenten selbsständiger werden. Das Thema des autonomen Lernens ist zwar nicht neu, aber gerade heute wird es immer aktueller. Akmeologischer Ansatz im modernen Ausbildungssystem besteht darin, Erfolg zu erreichen. Dazu führt professionelle Motivation, Entwicklung des kreativen Potenzials und anderer persönlichen Ressourcen. Akmelinguistik beschreibt Faktoren, Mechanismen und GesetzmäBigkeiten der Entwicklung und Selbstaktualisierung der erwachsenen Lernenden für die besten Ergebnisse beim Sprachenlernen.

Schlüsselwörter: Ausbildung; akmeologische Forschung; Akmelinguistik, individueller Bildungsweg; Bildungstechnologien; akmeologische Entwicklung; Selbstaktualisierung.
\end{abstract}

\section{Einführung}

In der Epoche der globalen innovativen Prozesse beobachtet man den Fortschritt nicht nur im technischen oder wissenschaftlichen Bereich, sondern auch in der Ausbildung. Es werden neue Standarts, Ausbildungsmethoden entwickelt. Der technische Fortschritt und die moderne Raumausstattung in den Universitäten tragen auch dazu bei, die methodisch didaktischen Möglichkeiten der Ausbildung zu vervollkommnen. Studenten werden selbständiger, denn die Kenntnisse werden zugänglicher -man kann jede Information im Internet bekommen. Das Thema des autonomen Lernens ist zwar nicht neu, aber gerade heute wird es immer aktueller. Als Linguisten interessieren wir uns aber in erster Linie für Verbindung der Linguistik mit anderen Wissenschaften und Möglichkeiten der Autonomie auf dieser Grundlage.

Nach N.N. Nechajev und A.A. Verbitsky besteht das Hauptziel der Ausbildung darin, dass jeder Lernende nicht nur die vergangene kulturelle Erfahrung aufnimmt, sondern auch sie dadurch bereichert, dass er sich als eine bildende Person entwickelt, dass er bereit ist, in den entsprechenden gesellschaftlichen und wirtschaftlichen Bedingungen zu arbeiten [1: 14]. Die moderne Ausbildung setzt neue Ziele, die zu einem neuen Kompetenzniveau einer Person führen. Von großem Interesse ist für uns eine Ausbildung, die als Ergebnis die Beherrschung einer Fremdsprache hat. Akmeologischer Ansatz im modernen Ausbildungssystem besteht darin, Erfolg zu erreichen. Dazu muss man die professionelle Motivation verstärken, Implementierung 
des schöpferischen Potentials anregen, persönliche Ressourcen erkennen und wachsen lassen.

\section{Forschung}

Akmelinguistik - ist eine neue, aktuelle wissenschaftliche Forschungsrichtung in der Akmeologie. Der Begriff Akmelinguistik ist relativ neu und bezeichnet wissenschaftliche und praktische Tätigkeit der Lehrer, die die Faktoren, Mechanismen und Gesetzmäßigkeiten der Entwicklung und Selbstaktualisierung der erwachsenen Lernenden für die besten Ergebnisse beim Sprachenlernen untersucht. Anders gesagt, die Fremdsprache wird als ein Mittel fürs Erreichen des persönlichen Akme betrachtet [2:39].

N.W. Kuzmina und A.M. Zimicheva beschreiben folgende Besonderheiten der Akmelinguistik:

1. Systematischer Ansatz beim Sprachenlernen: man erforscht die Gesetzmäßigkeiten akmeologischer Entwicklung, produktive Ausprägung aller persoenlichen Eigenschaften, die auf die Lösung von wichtigen Problemen durch Sprachenbeherrschung orientiert sind;

2. Benutzen von methodologischen Prinzipen des modernen Wissens und akmeologischer Grundlage, die dazu geeignet ist, das Zusammenwirken mit anderen Wissenschaften zu unterstützen;

3. Akmelinguistik untersucht psychologische Kategorien der Persönlichkeit und Tätigkeit des Lernenden, verschafft eine Art Synthese zwischen der Psychologie und der Erziehungswissenschaft. Dabei nimmt die Akmelinguistik die subjektorientierte Position, wo der Lernende als Subjekt des Bildungsvorgangs auftritt mit der Festlegung von integrativen Bindungen zwischen allen Teilnehmern und Komponenten dieses Prozesses;

4. Ausarbeitung eines Akmeogramms: selbständiger Erwerb und Erweiterung der Kenntnisse, Bildung und Entwicklung von Fähigkeiten und Fertigkeiten durch autonomes Lernen und Selbstaktualisierung;

5. Berücksichtigung psychophysischer, sozialer und anderer Besonderheiten der Lernenden;

6. Hierarchie im Lernstoff;

7. Befolgung der Akmeoethik: Fähigkeit der Meinungsäußerung in der Fremdsprache [N.W. Kuzmina, A.M. Zimicheva, S. 248].

Das Forschungsobjekt der Akmelinguistik ist „die Sprachtätigkeit, die die Beziehung zwischen der kommunikativen und der psychokognitiven Tätigkeit der Menschen zum Ausdruck bringt und von der Weltanschauung, Lebensansichten und Werten der Person abhängig ist." [6: 252]

Heutzutage ist der größte Teil der Forschungen in diesem Bereich auf die Bildung der professionellen sprachlichen Kultur von Lehrer ausgerichtet, deswegen ist die Frage der akmeologischen und akmelinguistischen Entwicklung der Studenten von Fremdsprachenfakultät ein aktuelles Problem. 
Die professionelle sprachliche Kultur der zukünftigen Fachleute spielt im Leben der zukünftigen Linguisten eine wichtige Rolle, weil sie hauptsächlich Charakter, persönliche Besonderheiten, Belehrbarkeit und Verhältnis zu einem Gesprächspartner demonstriert. Aus heutiger Sicht ist die Fähigkeit, richtig zu sprechen und kompetent zu argumentieren, eine der wichtigsten Anforderungen an einen Linguisten.

Akmelinguistik lässt die Ausbildung auf Motivationsentwicklung von Studenten, Selbstständigkeit und Kreativität umorientieren. Sie bringt einen hohen Kreativitätsgrad, der auf Studentenmotivation basiert. Die wichtigsten Bedingungen des Erreichens von dem Akme-Zustand in der beruflichen Taetigkeit sind Motivation (Erfolgsquelle, Arbeitsqualitätsbestreben, Fähigkeit sich selbst zu motivieren), Optimismus und Selbstsicherheit [4]. Wenn ein Mensch das Objekt seiner Tätigkeit findet, wird dieses Objekt ein Ziel des Subjektes. Die Motivation ist der Hauptfaktor in Persönlichkeitsstruktur und stellt einen der Hauptbegriffe dar, den man für Erklärung der Benehmensund Tätigkeitsbewegungskräfte benutzt. Motivation, Kreativität und Intellekt sind die wichtigsten Faktoren von Persönlichkeitsentwicklung [5]. Demzufolge kann man Akmelinguistik heutzutage als innovative Unterrichtstechnologie bezeichnen, weil sie auf Umdenken von klassischen Bildungszielen in Übereinstimmung mit den realen Berufsbedürfnissen des zukünftigen Fachmanns gerichtet ist [6:179].

Unserer Ansicht nach ist die Forschung akmeologischer Komponente des Motivationbereiches von Master-Studenten der Fremdsprachenfakultäten und Suche nach individuellen Bildungswegen sehr aktuell und fortschrittlich.

Nicht alle Masterstudenten der Fremdsprachenfakultäten haben Fremdsprachenstudium hinter sich. Bei den Studenten mit dem ehemaligen studienbegleitenden Fremdsprachenunterricht passiert während des Masterstudiums an der Fremdsprachenfakultät die akmeologische Entwicklung auf der Grundlage der Fremdsprache. Es ist interessant zu erforschen, auf welche Weise sie motiviert und in welcher Richtung wird sich ihr Akme entwickeln. Wir bereiten eine empirische Studie zu diesem Thema vor. Im Rahmen dieser Studie werden 60 Menschen abgefragt. Die erste Gruppe besteht aus den Masterstudenten, die Fremdsprachen studienbegleitend gelernt haben und ihre Ausbildung an der Fremdsprachenfakultät fortsetzen. Die zweite Gruppe besteht aus den Absolventen der Fremdsprachenfakultäten. Das Ziel unserer Forschung ist herauszufinden, was die Teilnehmer animieret hat, diese Wahl zu treffen und wie das ihr Akme betroffen hat, welche Ergebnisse Sie in der Zukunft erwarten.

Das Experiment wird nach einem bestimmten Modell durchgeführt, das wir erarbeitet haben.

Das Modell des individuellen Bildungswegs.

Bei der Entwicklung des individuellen Bildungswegs muss man alle notwendigen Elemente berücksichtigen: 
1) den zielgebundenen Bestandteil (Ziel- und Aufgabensetzung);

2) den auf den Inhalt bezogenen Bestandteil (Identifizierung des inhaltsbezogenen Bestandteils, Festlegung der Themen, der Bildungsrichtungen);

3) Planung;

4) Reflexion.

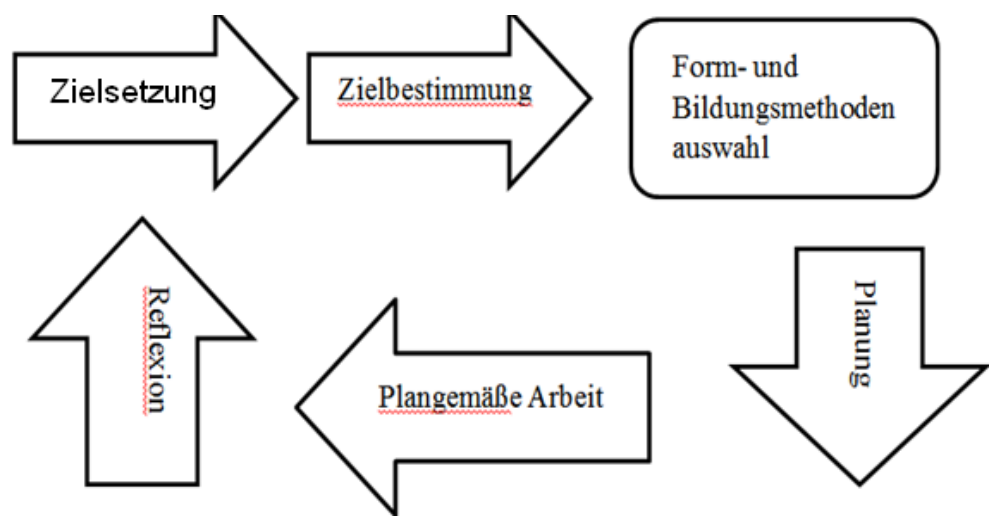

Bild 1. Das Modell des individuellen Bildungswegs

\section{Fazit}

Um die Ergebnisse richtig zu bewerten, muss man analysieren, ob die Masterstudenten die gesetzten Ziele erreicht haben. Falls es nicht geklappt hat, muss man feststellen, worin der Grund besteht und welche Lösungen existieren. Während des Expriments und nach dem Abschluss des Experiments planen wir ein akmeologisches Tagebuch zu führen, wo die Untersuchungen des Akme-Zustandes der Masterstudenten beschrieben werden, die früher Fremdsprachen nicht studiert haben.

\section{Literaturverzeichnis}

1. Nechaev, N.N., Verbitsky, A.A.: Pedagogika, psikhologiya i zadacha sovershenstvovaniya uchebnogo protsessa v vuze [Pedagogy, psychology, and the task of improving the educational process at university] // Fundamentals of pedagogy and psychology of higher education. Moscow, MSU. pp. 13-23. (1986). (In Russian)

2. Akimova, O.B. Akmelingvistika kak ponyatiye pedagogicheskoy akmeologii [Acmelinguistics as the concept of pedagogical acmeology] // Acmeology of Vocational Education: materials of the 10th All-Russian Scientific and Practical conference, Yekaterinburg, March 13-14, 2013. / Russian State Professional and Pedagogical University. pp. 38-42. (2013). (In Russian)

3. Kuzmina, N.V., Zimicheva, A.M.: Akmeologiya. Metodicheskiye i metodologicheskiye problemy [Acmeology. Methodological and methodological problems]. SPb. SPbAA. (2000). (In Russian) 
4. Derkach, A.A.: Akmeologicheskiye osnovy razvitiya professionala [Acmeological basis of professional development]. Moscow. Vorohezh. (2004). (In Russian)

5. Abolina, N.S.: K probleme razvitiya kreativnosti lichnosti v protsesse professionalizatsii [To the problem of the development of the creativity of the individual in the process of professionalization] / Acmeology of Vocational Education: materials of the 6th AllRussian Scientific and Practical conference, Yekaterinburg, May 19-20, 2009. pp. 18-23. (2009.) (In Russian)

6. Rumyantseva, L.N.: Tekhnologii obucheniya inostrannym yazykam tret'yego tysyacheletiya s pozitsii akmelingvistiki [Technologies for teaching foreign languages of the third millennium from the position of acmelinguistics]. SPb. (2003). (In Russian)

\section{AKMEOLINGUISTIC IN THE CONTEXT OF INDIVIDUAL EDUCATION \\ Merts E.A.}

Abstract. In recent times big changes occur in education, which became an impetus in revision of the basic characteristics of the educational problems, and in particular in teaching foreign languages. Modern education leads to a new level of individual education. In the article is considered the issue of the acmeological approach in education. In the pedagogical literature is actively using the relatively recent term "acme linguistics". Akmeolinguistics is a new, relevant scientific direction of research, the language here as a means of achieving personal "acme". The acmeological approach is one of the progressive and promising for the modern school. At the moment, most studies in this area are aimed at the formation of the vocational and speech culture of teachers, so the issue of acmeological and acmeolinguistic development of students of the language faculty is an actual problem. Language education is an obligatory component of the student's professional training. The standards for teaching foreign languages include both established and innovative training models: a person-oriented approach, continuity of education, cognition, interdisciplinarity, individual education, acmeological approach, etc. The pedagogical process must transform culture into abilities that serve as a prerequisite for the development of professional abilities and skills in the system of communication and social relations. The authors raise the question of the concept and essence of individual paths of study. Four components of realization of individual educational trajectories are singled out and characterized: the target component, the content component, the technological component and the reflection. The authors of the article provide a detailed model for the construction of an individual educational trajectory.

Keywords: language education; acmeolinguistics; individual educational trajectory; education technologies.

\section{Information about the authors:}

Merts E.A. - master student, Faculty of Foreign Languages, Tomsk State University (Tomsk, Russia). E-mail: Merts.ekaterina@gmail

Zhitkova E.V. - Ph.D., Associate Professor, Head of Departement of the German Language, National Research Tomsk State University (Tomsk, Russia). E-mail: eshi@inbox.ru 